\title{
Honoré de Balzac, Il Cugino Pons
}

\section{Marco Stupazzoni}

\section{(2) OpenEdition}

\section{Journals}

\section{Edizione digitale}

URL: https://journals.openedition.org/studifrancesi/4731

DOI: 10.4000/studifrancesi.4731

ISSN: 2421-5856

\section{Editore}

Rosenberg \& Sellier

\section{Edizione cartacea}

Data di pubblicazione: 1 avril 2012

Paginazione: 164

ISSN: 0039-2944

\section{Notizia bibliografica digitale}

Marco Stupazzoni, «Honoré de Balzac, // Cugino Pons», Studi Francesi [Online], 166 (I | LVI) | 2012, online dal 30 novembre 2015, consultato il 19 novembre 2021. URL: http://journals.openedition.org/ studifrancesi/4731; DOI: https://doi.org/10.4000/studifrancesi.4731

\section{Questo documento è stato generato automaticamente il 19 novembre 2021.}

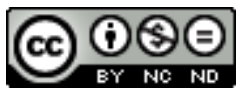

Studi Francesi è distribuita con Licenza Creative Commons Attribuzione - Non commerciale - Non opere derivate 4.0 Internazionale. 


\title{
Honoré de Balzac, Il Cugino Pons
}

\author{
Marco Stupazzoni
}

\section{NOTIZIA}

HONORÉ DE BALZAC, Il Cugino Pons, introduzione, traduzione e note di Lanfranco BINNI, Milano, Garzanti, «I grandi libri», 2011, pp. LXVI-321.

1 Pubblicato in prima edizione nel «Constutionnel» dal 18 marzo al 10 maggio 1847, Le Cousin Pons rappresenta una testimonianza straordinaria e forse unica, nella Comédie humaine, dell'ultimo Balzac, alla vigilia della Rivoluzione del 1848. Quella che qui segnaliamo è la seconda edizione della traduzione italiana che, del romanzo balzachiano, ha fornito Lanfranco Binni nel 1996 insieme all'esemplare saggio introduttivo, aggiornato, per l'occasione, nell'apparato bibliografico, che percorre dettagliatamente l'intenso itinerario biografico-letterario dello scrittore.

2 Tra gli elementi centrali del romanzo, v'è sicuramente la figura di Pons, ma soprattutto la descrizione della sua collezione d'arte. Nel romanzo, la cui composizione si intreccia da vicino con alcune, tristi, vicende personali di Balzac e con la scrittura della Cousine Bette, è soprattutto l'atteggiamento nei confronti dell'arte e del collezionismo a creare un legame strettissimo tra Pons ed il suo creatore. Pons appartiene alla categoria dei "vinti", di quei personaggi umiliati e schiacciati da una società dominata dalla logica del denaro, in cui non v'è più posto per sentimenti disinteressati come l'amicizia o l'amore dell'arte. Ecco allora che la collezione si configura come «mondo separato osserva Binni -, a parte rispetto ai valori sociali correnti, come universo disinteressato (la Bellezza come valore assoluto) rispetto all'avidità mercantile che trasforma tutto, uomini e cose, in merci da comprare e da vendere»: è, in altri termini, «uno strumento di separazione esistenziale da una società di cui Balzac ha ripetutamente illustrato $i$ meccanismi disumani e spietati» (p. LVIII). 